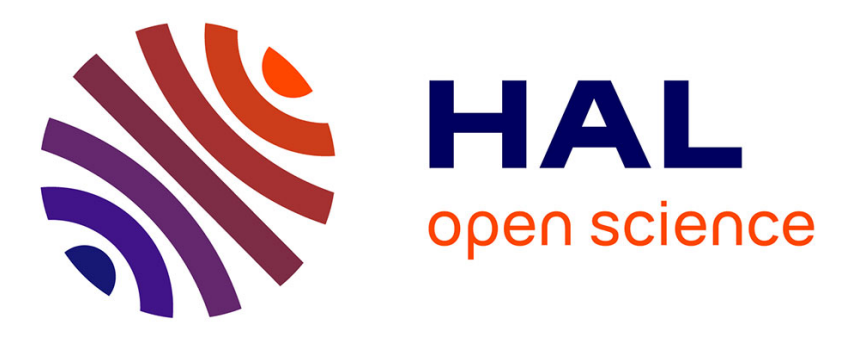

\title{
Correction to "Water-stable isotopes in the LMDZ4 general circulation model: Model evaluation for present-day and past climates and applications to climatic interpretations of tropical isotopic records"
}

\author{
Camille Risi, Sandrine C Bony, Françoise Vimeux, Jean Jouzel
}

\section{To cite this version:}

Camille Risi, Sandrine C Bony, Françoise Vimeux, Jean Jouzel. Correction to "Water-stable isotopes in the LMDZ4 general circulation model: Model evaluation for present-day and past climates and applications to climatic interpretations of tropical isotopic records". Journal of Geophysical Research: Atmospheres, 2010, 115 (D24), 10.1029/2010JD015242 . hal-03108520

\author{
HAL Id: hal-03108520 \\ https://hal.science/hal-03108520
}

Submitted on 22 Oct 2021

HAL is a multi-disciplinary open access archive for the deposit and dissemination of scientific research documents, whether they are published or not. The documents may come from teaching and research institutions in France or abroad, or from public or private research centers.
L'archive ouverte pluridisciplinaire HAL, est destinée au dépôt et à la diffusion de documents scientifiques de niveau recherche, publiés ou non, émanant des établissements d'enseignement et de recherche français ou étrangers, des laboratoires publics ou privés.

$$
\text { Copyright }
$$




\title{
Correction to "Water-stable isotopes in the LMDZ4 general circulation model: Model evaluation for present-day and past climates and applications to climatic interpretations of tropical isotopic records"
}

\author{
Camille Risi, Sandrine Bony, Françoise Vimeux, and Jean Jouzel \\ Received 5 November 2010; published 31 December 2010. \\ Citation: Risi, C., S. Bony, F. Vimeux, and J. Jouzel (2010), Correction to "Water-stable isotopes in the LMDZ4 general \\ circulation model: Model evaluation for present-day and past climates and applications to climatic interpretations of tropical \\ isotopic records," J. Geophys. Res., 115, D24123, doi:10.1029/2010JD015242.
}

[1] The paper "Water-stable isotopes in the LMDZ4 general circulation model: Model evaluation for presentday and past climates and applications to climatic interpretations of tropical isotopic records" by C. Risi et al. (Journal of Geophysical Research, 110, D12118, doi:10.1029/ 2009JD013255, 2010) contains a misstatement. In LMDZ the same advection scheme can be used to mimic either a simple upstream scheme [Godunov, 1959] or Van Leer's second-order advection scheme [Van Leer, 1977] depending on one tunable parameter [Hourdin and Armengaud, 1999]. Contrary to the description in section 2.1 of our paper, the advection scheme in our simulations was set as the simple upstream scheme rather than Van Leer's scheme. This has little influence on the results presented in the paper. Appendix A on the implementation of water vapor isotopes in the advection scheme remains valid. A comparison of the isotopic distribution simulated for these two advection schemes will be documented in forthcoming papers (F. Vimeux et al., A strong control of the South American SeeSaw on the intraseasonal variability of the isotopic composition of precipitation in the Bolivian Andes, submitted to Earth and Planetary Science Letters, 2010, and C. Risi et al., Process-evaluation of tropical and subtropical tropospheric humidity simulated by general circulation models using water vapor isotopic observations, submitted to Journal of Geophysical Research, 2010).

\section{References}

Godunov, S. K. (1959), Finite-difference methods for the numerical computations of equations of gas dynamics, Math. Sb., 7, 271-290.

Hourdin, F., and A. Armengaud (1999), The use of finite-volume methods for atmospheric advection of trace species. Part I: Test of various formulations in a general circulation model, Mon. Weather Rev., 127, 822-837. Van Leer, B. (1977), Towards the ultimate conservative difference scheme: IV. A new approach to numerical convection, J. Comput. Phys., 23, 276-299. 